Article

\title{
Impact Evaluation of the Provision of Social Housing on the Use of Social Services by Homeless People in the Czech Republic
}

\author{
Katerina Glumbikova ${ }^{1, * \mathbb{D}}$, Pavel Rusnok ${ }^{2}$ and Marek Mikulec ${ }^{1}$ \\ 1 Department of Social Work, University of Ostrava, 70900 Ostrava, Czech Republic; marek.mikulec@osu.cz \\ 2 Institute for Research and Applications of Fuzzy Modeling, University of Ostrava, \\ 70900 Ostrava, Czech Republic; pavel.rusnok@osu.cz \\ * Correspondence: katerina.glumbikova@osu.cz
}

Received: 1 November 2020; Accepted: 4 December 2020; Published: 6 December 2020

check for updates

\begin{abstract}
The Czech Republic has recently experienced a growing number of homeless people, which leads to the need to evaluate the impact of social housing on the living conditions of its users. At present, there is no existing law on social housing in the Czech Republic and the agenda of assistance to the homeless is thus carried out mainly by social services. For these reasons, the paper intends to evaluate the impact of social housing on the homeless in the Czech Republic in a specific area of the use of social services. Based on a quantitative research survey of 147 social housing dwellers after moving in and after 12 months, the impact of social housing on the use of social services was determined, which was put into context with the trend of using social work services in social housing. Research results show that the provision of social housing leads to an overall decrease of the social work utilization and (possible) increase in client self-sufficiency, which can result in strong economic impacts of social housing in the form of savings on social work provision.
\end{abstract}

Keywords: social housing; impact evaluation; social services

\section{Introduction}

There are four reasons for the desirability of the paper's creation, namely: (a) the growing number of homeless people and people at risk of homelessness; (b) the absence of law on social housing, which would require municipalities to provide social housing; (c) existing barriers in using social work services; and, (d) the need for evidence on the impact of social housing on homeless people in the Czech Republic. We understand social housing as housing provided to persons in need of housing or who are at immediate risk of housing loss. Social housing is provided under specific rental terms and conditions and in accordance with certain principles. Users of social housing are provided with support in the form of social work, if necessary.

Concerning (a): The number of homeless people is growing, as reported by research at the national and international levels [1]. According to the Homeless People Census [2], in the spring of 2019 , there were a total of approximately 23,830 homeless persons in the Czech Republic, of whom 2600 were children. In 2011, the number was only 11,496 homeless people. All ETHOS (European typology of homelessness and housing exclusion) categories of homeless people were included in this census. This number can be considered high, as it is $0.2 \%$ of the population of the Czech Republic.

Concerning (b): At the same time, there is no law on social housing in the Czech Republic, which would require municipalities to provide social housing for their residents in need of housing. Discussions about the need for the law have been ongoing in the Czech environment for a long time.

There was a shift in preparations in 2014, when the Ministry of Labour and Social Affairs became the main administrator and prepared the Concept of Social Housing in the Czech Republic 2015-2025 [3]. 
The concept defined the parameters of a social housing system and prepared the wording of the Social Housing Act and Housing Allowance Act. The law was approved by the Czech government [4], but it failed to pass the legislative process. Since February 2018, the Ministry of Regional Development has been reinstated as the main administrator, resulting in a partial change in perspective shown as a shift toward an affordable housing law [5].

In the context of the above, there are only some municipalities (currently not more than 40) that piloted their own social housing systems, thus ensuring the provision of social housing to persons in need of housing. However, the individual social housing systems differ considerably in the principles used for social housing provision, with some municipalities implementing the Housing Ready principle (Housing Ready consists of several housing levels with different intensities of obligatory social work. Accommodation in individual stages of permeable housing is thus time limited. The move between the individual levels of housing is understood as a motivating factor and is related to a household's move. Independent living is the last step.), and others the Housing First principle (Housing First uses housing as a starting point rather than an end goal. The Housing First approach is based on eight core principles: 1 . Housing is a human right. 2. Choice and control for service users. 3. Separation of housing and treatment. 4. Recovery orientation. 5. Harm reduction. 6. Active engagement without coercion. 7. Person-centred planning. 8. Flexible support for as long as is required [6]).

In the Czech Republic, there is also a system project of the Ministry of Labour and Social Affairs to support social housing: Social housing-methodological and information support in the area of social agendas (CZ.03.2.63/0.0/0.0/15_017/0003539), which aims to "establish and develop a social housing system in the Czech Republic through international cooperation, research activities, methodological materials and the establishment of a Contact Centre, employees of which participate in the piloting of the social housing system according to the Concept of Social Housing in the Czech Republic 2015-2025 and will provide methodological support." A total of 16 municipalities in the Czech Republic piloting implementation of local social housing systems are involved in the project. These pilot social housing systems have the makeup of European Union-funded projects.

Social work with clients accommodated in social housing is one of the basic preconditions for successful retainment of social housing and is provided in individual social housing projects, both in the outpatient and field form. Its goals include stabilization of settled-in households, cooperation in retaining the flat and subsequent gradual addressing of issues set out in the client's individual service plan. The level of support intensity, forms and methods of social work must be determined individually according to the needs and situation of the client [7]. The most common areas of support include support in dealing with the authorities (including the provision of social housing benefits), legal assistance and counselling, support for social contacts (relationships with family, friends), job search, money management, but also, e.g., support for creating a daily regime or door management [8].

Concerning (c): The abovementioned facts reveal that the assistance and help to homeless people in the Czech Republic are currently primarily in the agenda of social services [9]. Homeless people are supported on the street by a variety of field programmes. The most frequently used form of assistance is shelters. Shelters are a social service that provides temporary accommodation for a fee (primarily for the period of one year) to persons in an unfavourable social situation associated with the loss of housing in combination with social work.

Concerning (d): There are numerous studies on the impacts of social housing on the homeless abroad; see, for example, [10-16]. The Czech Republic has only a very limited number of studies dealing with the impact of the provision of social housing on the living situation of homeless people. The very first study was the study of Ripka et al. [17], who carried out a social housing impact evaluation after 12 months in the Rapid Re-housing project for 50 families, funded by the city of Brno, which can be considered essential in this area. Research shows that $96 \%$ of people were able to keep housing in this social housing project. This research is so far the only research in the Czech Republic with which the results of the presented evaluation can be compared (see below). 
However, almost none of the presented studies deal with the effects of the use of social housing on the use of social services outside the social housing project. Only the study of Aubry et al. [12] pointed out that social housing has improved the availability of assistance when addressing social benefits, and the study of Ripka et al. [17] described the use of social services within the project, where the support of social work was necessary in social housing provided by an external organization (social service). As a result, this study states that significantly more frequent use of services was observed in households accommodated in social housing. The authors themselves state that this use was related to the activity of a key worker from that social service. Services to help with problems related to housing and to help with negotiations with the authorities and the settlement of social benefits were used the most. Our research thus tries to respond not only to the abovementioned justification of the need to evaluate the impacts of social housing on its users, but also to fill the research gap in the form of evaluating the impacts of social housing on the use of social services.

In the context of the above, this paper aimed to evaluate the impact of social housing on the homeless in the Czech Republic in the specific area of the use of social services determined by a search of Czech and foreign literature.

\section{Situation of Social Services for Homeless People in the Czech Republic}

In the Czech Republic, the category of social services for homeless people includes mainly: shelters (in ETHOS categorization, people living in shelters are roofless; ETHOS describes shelters as homeless hostels), night/emergency shelters (in ETHOS categorization, people sleeping in night shelters are houseless), low-threshold day centres, outreach programmes, social rehabilitation and social activation services. Cooperation with these services is based on the voluntariness and individual needs of each client. Most of the tenants of social housing were in contact with these services during their lives. Social workers working in these services help homeless people meet their individual needs. For residential service workers, assistance/help may be encountered with some monitoring of compliance with the facility's rules.

(A) Shelters that are described in [18] as follows: "Shelters provide accommodation services for a transitional period to persons in an adverse social situation associated with the loss of housing." The Social Services Act states that "The service ... includes the following basic activities: (a) Provision of food and/or assistance in the provision of food, (b) Provision of accommodation, (c) Assistance in the exercise of one's rights, legitimate interests and in the securing of one's personal affairs." The Social Services Act further states that "persons shall pay a fee for the provision of social services in temporary hostels ... "; the maximum amount of the compulsory payment is $130 \mathrm{CZK}$ per person per night (approx. $5 \mathrm{EUR}$ ). The stay in a hostel is limited in time, most often for a period of one year. The client sets up his/her individual service plan when entering the service, and works toward its fulfilment together with a social worker during the service use. Categories of the service provision rules can be summarized in three areas: 1 . Active work to solve one's adverse situation (according to the individual service plan); 2. Regular and timely payment for the services provided; 3 . Compliance with the stipulated house rules.

(B) Night/emergency shelters: [18] describes emergency accommodation/shelters as follows: "Emergency shelters provide outpatient services to homeless persons who are interested in the use of sanitary facilities and an overnight accommodation. The service ... includes the following basic activities (a) Assistance in personal hygiene or provision of conditions for personal hygiene, (b) Provision of overnight accommodation (including cleaning and bed linen replacement)." The service provision regime may show minor differences with regard to the service provider. Typically, however, the time is set for evening hours, which is when the services receive clients (e.g., 7:00-8:00 p.m.) and for morning hours, which is when the clients must leave the service (e.g., between 6:00 and 7:00 a.m.). Clients may use a sanitary facility, laundry service, and have a meal (e.g., soup). They are accommodated in 3-8-bed rooms. An overnight stay 
is subject to a fee of approximately $45 \mathrm{CZK}$ (approx. 1.5-2 EUR; however, a half-rate is not an exception) and laundry wash is approximately 15 CZK (approx. 0.6 EUR).

(C) Low-threshold day centres, as defined in [18], are as follows: "Low-threshold day centres provide outpatient or outreach services for homeless persons. The Service ... contains the following basic activities: (a) Assistance in personal hygiene or provision of conditions for personal hygiene; (b) Provision of food or assistance in providing food; c) Assistance in the exercise of rights, legitimate interests and securing of personal affairs." Services are provided free of charge in a low-threshold day centre. The low-threshold day centre offers meals, and clients can wash themselves and clothes here; and offers basic counselling assistance (for example, when dealing with common matters). The service is provided at predetermined hours, e.g., from 8:00 a.m. to 4:00 p.m.

(D) Outreach programmes as defined in [18] are as follows: "Outreach programmes are field services provided to persons who lead a risky life or whose life is at risk by this lifestyle. The service is intended for problematic groups of people, that is people addicted to drugs or other narcotic psychotropic substances, homeless people, people living in socially excluded communities, and other socially vulnerable groups. The service aims to seek and minimize the risks of their lifestyle. The service may be provided to people anonymously. The Service ... includes the following basic activities: (a) Contact mediation with the social environment, (b) Assistance in the exercise of rights, legitimate interests, and in the provision of one's personal affairs." Outreach programmes focus on searching for potential users of social services in their natural environment. This type of service enables contact with people who do not seek assistance themselves or refuse assistance. At the same time, the whole group or community social work is welcomed to be implemented, which can lead to a more thorough solution to the problems in a given location.

(E) Social rehabilitation as defined in [18] is as follows: "Social rehabilitation is a set of specific activities aimed at achieving autonomy, independence and self-sufficiency of persons by developing their specific abilities and skills, strengthening of their habits and training of performance of routine activities required for independent life in an alternative way using the preserved capabilities, potentials, and competencies. Social rehabilitation is provided in the form of outreach and outpatient services or in the form of residential services provided in centres for social rehabilitation services. The service ... provided in the form of outreach or outpatient services includes the following basic activities: (a) Training of skills required for self-care, self-sufficiency and other activities leading to social inclusion, (b) Mediation of contact with the social environment, (c) Educational and activation services, (d) Assistance in the exercise of their rights, legitimate interests and in the provision of personal affairs. The service ... provided in the form of accommodation services in the centres for social rehabilitation services includes, besides the basic activities described above, the following: (a) Provision of accommodation, (b) Provision of food, (c) Assistance in personal hygiene or ensuring conditions for personal hygiene".

(F) Social activation services for families with children as defined in [18] are as follows: "Social activation services are outpatient or outreach services in the field provided to persons of retirement age or to persons with disabilities at risk of social exclusion. The service according to ... contains the following basic activities: (a) Mediation of contact with the social environment, (b) Social therapeutic activities, (c) Assistance in the exercise of one's rights, legitimate interests and personal affairs." Social activation services often cooperate with social and legal protection bodies for children and defend the interests of the family.

In general, it can be stated that social services do not provide the homeless with long-term accommodation. At the same time, these services (excluding shelter and emergency shelter) are also intended for target client groups other than the homeless. Specific information on how these services are used by the homeless in the Czech Republic is lacking. We can only list that there were 78 emergency shelters in the Czech Republic used by 42,751 clients in 2018. There were also 217 temporary shelters used by a total of 5289 clients in 2018 [4]. 
Despite the fact that helping homeless people is mainly an agenda of social services, homeless people themselves identify a number of barriers to the use of social services.

In 2018, qualitative research with homeless people was realized in the Czech Republic. The main aim of this research was to analyse and describe the barriers to the use of public services by people without a home. A number of barriers to using social services were identified during qualitative interviews with homeless people who lived on the streets or slept in night shelters (41 interviews, 8 women and 33 men, average age of the informants was 46 years) [19].

This research revealed a number of barriers to the use of public services by people without a home, which were divided into the systemic (given by the system) and individual ones. The systemic included: a personal responsibility for systemic shortcomings (especially the lack of profitable housing and the absence of a law on social housing). The individual barriers (i.e., not on the informants' side but those identified by individuals) included two categories of barriers, i.e., the barriers to access social services and the barriers to stay in residential social services. The barriers to access the social services were the necessity to split the families (in case of cohabitation), absence of documents, lack of finances, medical examination, animal ownership, and negative experience with a particular service or worker (shared among the persons without a home). The barriers during the stay in residential social services were the set of rules (mainly cleaning the common premises and the alcohol tolerance), opening and waiting time (for placement), mental problems, necessity to share the room with "other clients", resulting lack of peace and privacy, and relationship dynamics of the environment.

The informants associated the (non-)use of services with their non-necessity and the need to solve "their own problems" with "their own invention" and "their own survival strategies". They frequently did not consider themselves to be social services clients (that is, people who need the help of services) and, on the contrary, they felt that there were "others" who needed the services more [19], and we also see foreign research with the same focus and target group, e.g., [20-22].

\section{Materials and Methods}

The presented data are partial data, which were created within the final evaluation of the project of social housing where 16 municipalities were involved (14 cities and 2 urban districts). These were municipalities of various sizes: there were three cities with less than 1000 inhabitants; three large cities with more than 150,000 inhabitants; the rest of the cities were medium size-it means that they have less than 90,000 inhabitants.

Based on a search of foreign studies [12], we assumed that there would be a decrease in the use of social services. We decided to verify this assumption, although it was not confirmed within the Rapid Re-housing project research with 50 households in one of the Czech cities (Brno) [17]. During this verification process, we focused on the five most common areas of the social services agenda (for more details, see the previous chapter) used by the homeless. These areas involved: assistance in dealing with authorities, assistance in arranging for social benefits, housing assistance, job search assistance, and debt assistance [23].

Data were collected through a questionnaire designed by the authors [23], which was also used in a similar form in the evaluations of the Rapid Re-housing Project [17], and which is based on meta-analysis of foreign experience. A total of 534 households were involved in the system project. The households involved in evaluation research were selected on the basis of intentional sampling realized by individual municipalities. Each of the municipalities selected households in its local social housing projects that were involved in the survey. The criterion for selection was the involvement in a local social housing project.

As part of the assisted questionnaire survey, a questionnaire mapping the conditions in households provided with social housing was used. Also, the questionnaire was administered right after moving into a new accommodation and then after 12 months, with one representative of the household who reported on the surveyed household's conditions. The questionnaire consisted of 61 questions to be asked after moving in, and 47 questions to be asked after 12 months. The questions focused on various 
areas of the life situation, such as the experience of need of housing, the financial situation of the household, employment, health status, social relationships and the use of social services.

The researchers managed to match up the questionnaire versions administered at the time of moving in with after 12 months for 147 respondents, of which 53 were men and 94 women. Each respondent responded as a representative of the whole household, so gender differences were not monitored. The average age of the respondents was 40.7 years (minimum age: 19, maximum age: 75 ). A total of 75 of these respondents had a primary education, 18 respondents from this group had a secondary education with a school-leaving exam, 49 respondents had a secondary education with an apprenticeship certificate, 4 of these respondents had a university degree, and one respondent was without an education. Of note, 86 respondents were single, 45 divorced, 15 married, and one respondent was widowed. The average number of permanently residing household members in this respondent group was 2 and the maximum was 8 . The average number of permanently residing children under the age of 18 was 1 (or 1.2), while the maximum number of permanently residing children was 6 .

If we divided the respondents according to the last place of residence, we can state that: 29 respondents resided in a hostel; 33 respondents resided in a shelter; 8 respondents resided in housing, which they referred to as "cottage or cabin"; 6 respondents were roofless; 44 respondents came from rental housing and 20 respondents temporarily stayed with their relatives or friends in a private or separate room. The remaining respondents did not state their place of residence. If we use the ETHOS typology [24], there were: 62 houseless persons, 8 persons from inadequate housing, 6 roofless persons and 64 persons from insecure housing. We have intentionally used the ETHOS typology, considering that it can provide a comparison of results in an international context. At the same time, however, it is necessary to be aware of the difference between the target group of people living in hostels and shelters; when homeless people from the category of roofless people can also be future clients of shelters rather than people living in hostels. This similarity between the two subgroups is further reflected in the data results themselves.

The collected data were described by descriptive statistics, adjusted for erroneous and missing values. The common statistical methods depending on the type of set hypotheses were used for the processing of the collected data; specifically, it was the sign test and the Mann-Whitney test. These tests were used in relation to the fact that the data were nonparametric in nature. The sign test is a nonparametric test, which replaces a classical $t$-test when the assumption of a normal distribution is not met. The ratio between negative and positive nonzero differences in pair observations becomes a parameter of binomial distribution. Thus, the null hypothesis of the equality of that ratio to be one-half is then tested.

The Mann-Whitney tests whether a randomly selected quantity from one population will be lower or greater than a randomly selected value from another population. This is to test a general shift in the distribution, and therefore this test manages to reveal a difference even for variables that have identical medians.

The research followed the ethical principles set in the Unified Methodology for Monitoring and Evaluation of Local Social Housing Systems [23], which was in line with the valid legislation of the Czech Republic and which placed special emphasis on: maintaining confidentiality, ensuring awareness of research participants, ensuring safety and security for research participants, and voluntary participation in research.

We should reflect the research limits, which were caused by: (a) possible social desirability of the respondents (the level of readiness to respond the way the respondent believes that an interviewer wishes to hear); (b) nonrandom sampling of respondents; (c) sample size; (d) the nature of some questions, such as questions inquiring about a respondent's mental state, which interferes with privacy of respondents and at the same time places high demands on respondent's reflection; (e) inhomogeneity of the research sample due to a different nature of the respondent's life situation, a different context of individual municipalities involved in the project and a different approach of individual municipalities to social housing; (f) involvement of different evaluators in different municipalities, who, despite the 
fact that they were trained in the use of a uniform evaluation methodology, could bring their own perspective to the research and thus to the data; and, g) focusing on one specific area of evaluation of the impacts of social housing without monitoring the connection with other changes in the living situation of households in social housing. Even so, the research provides unique data on the impact of social housing in the Czech Republic.

\section{Results}

After moving in, and 12 months after the first round of interviews, respondents were asked how frequently they used selected services or the help offered by authorities on a three-point scale (often-sometimes-not at all) in the last six months. In this context, we also define the social services described in this article, i.e., as certain social assistance provided by social service organizations or offered by authorities. In statistical analyses, we also worked with data from respondents who frequently use social services.

Contrary to our assumption of an increased use of services in a total data sample, there was a decrease in the use of social services across target groups in the following monitored areas: dealing with authorities, arrangement for social benefits, and especially the area of housing assistance.

On the contrary, there was an increase in the use of social services in the area of debt-solving assistance in some target groups, which can be considered as a significant positive impact of social housing. The provision of social housing and related social work therefore leads to a decrease in the use of specific social services and, conversely, to an increase in the use of social services aimed at resolving debt issues. This fact can be explained by the newly emerging focus of social housing users on this issue due to stabilization of their living conditions and saturation of housing needs. It is also important to mention that debts may have arisen precisely as a result of the previous housing situation in the form of energy debts, which are often associated with the situation of households living in substandard housing, see, e.g., [25]. At the same time, social workers in social housing systems focus directly on working with debts and energy debts.

In the total data sample:

- $\quad$ the need for assistance in dealing with authorities dropped by $12 \%(\mathrm{n}=147, p$-value $=0.004)$;

- the need for assistance in arranging for social benefits dropped by $14 \%(\mathrm{n}=147, p$-value $<0.001)$

(Note: social benefits must be applied for repeatedly in the Czech Republic);

- $\quad$ the need for housing assistance dropped by $27 \%(n=147, p$-value $<0.001)$.

On the contrary, the need for assistance in resolving debt issues increased by $7 \%(\mathrm{n}=147, p$-value $=0.026$ ). It means that people in social housing may want to try to stabilize their financial situation after stabilizing their housing situation.

The use of social services in the area of job search did not change in the total data sample (respectively, it increased statistically insignificantly by $1.4 \%$ (from $13.6 \%$ to $15 \%$, $p$-value $=0.423$ ). This result corresponds with the results of the evaluation in the job search area, where the employment rate among social housing dwellers also did not change statistically significantly. The similar result is also presented by a number of research studies in the Czech environment [17]. It is compared to foreign research studies (see, e.g., [11]), where the number of the employed increased.

The factors we also monitored were the changes in the use of social services by respondents divided by the average intensity of social work support into less than three contacts per month $(n=50)$, three to four contacts per month $(n=44)$ and five and more contacts per month $(n=44)$. When dividing the target group by an intensity of the use of social work in supported housing, the highest decreases in the needs for support were in dealing with authorities (a decrease by $16 \%, \mathrm{n}=44, p$-value $=0.074$ ), arrangement for social benefits (by $16 \%, \mathrm{n}=44, p$-value $=0.02$ ), and the housing situation assistance (by $32 \%, \mathrm{n}=44, p$-value $=0.001$ ) for the target group with five or more contacts with social workers on a monthly basis. There was a decrease in the need to receive housing assistance in all target groups. Social housing therefore seems to lead to a reduction in the use of social services aimed at solving 
the clients' housing issue. The intensity of support from social workers can be a factor that affects the rate of use of social services. At the same time, it must be taken into account that a target group with five or more monthly contacts with social workers may be the target group moving into social housing, solving perhaps their most difficult life situation.

The following Table 1 shows in detail the presented results (except for the area of employment and job search, where there were no changes), including the respondent categorization using an ETHOS typology.

Table 1. Results of statistical data analysis.

\begin{tabular}{|c|c|c|c|c|c|c|}
\hline ETHOS & Target Group & $\mathbf{n}$ & $\begin{array}{c}\text { After } \\
\text { Moving In }\end{array}$ & $\begin{array}{l}\text { After } 12 \\
\text { Months }\end{array}$ & $\begin{array}{l}\text { Variation } \\
(\%)\end{array}$ & $\begin{array}{c}\text { Statistical Test } \\
(p \text {-Value })\end{array}$ \\
\hline \multicolumn{7}{|c|}{ Assistance in dealing with authorities } \\
\hline & Total data sample & 147 & $35.4 \%$ & $23.8 \%$ & -11.6 & 0.004 \\
\hline \multirow[t]{2}{*}{ Houseless } & $\begin{array}{l}\text { Previous place of residence } \\
\text { (PPR) (Previous place of } \\
\text { residence) hostel }\end{array}$ & 29 & $41.4 \%$ & $20.7 \%$ & -20.7 & 0.035 \\
\hline & PPR shelter & 33 & $18.2 \%$ & $27.3 \%$ & 9.1 & 0.227 \\
\hline Inadequate & PPR cottage or cabin & 8 & $62.5 \%$ & $12.5 \%$ & -50.0 & 0.062 \\
\hline Roofless & $\begin{array}{l}\text { PPR emergency shelter, } \\
\text { roofless }\end{array}$ & 6 & $16.7 \%$ & $33.3 \%$ & 16.7 & 0.5 \\
\hline \multirow[t]{2}{*}{ Insecure } & $\begin{array}{l}\text { PPR rental/own housing } \\
\text { (There were only } 3 \text { people } \\
\text { from own housing.) }\end{array}$ & 44 & $31.8 \%$ & $13.6 \%$ & -18.2 & 0.019 \\
\hline & $\begin{array}{c}\text { PPR transitional } \\
\text { (temporary) housing }\end{array}$ & 20 & $45.0 \%$ & $35.0 \%$ & -10.0 & 0.313 \\
\hline \multirow[t]{4}{*}{-} & Other & 4 & $50.0 \%$ & $50.0 \%$ & 0.0 & - \\
\hline & $\begin{array}{l}\text { less than } 3 \text { contacts with a } \\
\text { social workper month }\end{array}$ & 50 & $38.6 \%$ & $31.8 \%$ & -6.8 & 0.019 \\
\hline & $\begin{array}{c}3 \text { to } 4 \text { contacts with a SW } \\
\text { per month }\end{array}$ & 44 & $45.5 \%$ & $36.4 \%$ & -9.1 & 0.194 \\
\hline & $\begin{array}{l}5 \text { and more contacts with a } \\
\text { SW per month }\end{array}$ & 44 & $26.0 \%$ & $10.0 \%$ & -16.0 & 0.074 \\
\hline \multicolumn{7}{|c|}{ Assistance in arranging for social benefits } \\
\hline & Total data sample & 147 & $30.6 \%$ & $16.3 \%$ & -14.3 & $<0.001$ \\
\hline \multirow{2}{*}{ Houseless } & $\begin{array}{l}\text { PPR (Previous place of } \\
\text { residence) hostel }\end{array}$ & 29 & $41.4 \%$ & $17.2 \%$ & -24.1 & 0.008 \\
\hline & PPR shelter & 33 & $15.2 \%$ & $21.2 \%$ & 6.1 & 0.313 \\
\hline Inadequate & PPR cottage or cabin & 8 & $50.0 \%$ & $12.5 \%$ & -37.5 & 0.125 \\
\hline Roofless & $\begin{array}{l}\text { PPR emergency shelter, } \\
\text { roofless }\end{array}$ & 6 & $16.7 \%$ & $33.3 \%$ & 16.7 & 0.5 \\
\hline \multirow[b]{2}{*}{ Insecure } & PPR rental/own housing & 44 & $22.7 \%$ & $6.8 \%$ & -15.9 & 0.033 \\
\hline & $\begin{array}{c}\text { PPR transitional } \\
\text { (temporary) housing }\end{array}$ & 20 & $50.0 \%$ & $20.0 \%$ & -30.0 & 0.016 \\
\hline \multirow[t]{4}{*}{-} & Other & 4 & $50.0 \%$ & $50.0 \%$ & 0.0 & - \\
\hline & $\begin{array}{c}\text { less than } 3 \text { contacts with a } \\
\text { SW per month }\end{array}$ & 50 & $20.0 \%$ & $8.0 \%$ & -12.0 & 0.055 \\
\hline & $\begin{array}{c}3 \text { to } 4 \text { contacts with a SW } \\
\text { per month }\end{array}$ & 44 & $38.6 \%$ & $25.0 \%$ & -13.6 & 0.073 \\
\hline & $\begin{array}{l}5 \text { and more contacts with a } \\
\text { SW per month }\end{array}$ & 44 & $36.4 \%$ & $20.5 \%$ & -15.9 & 0.02 \\
\hline
\end{tabular}


Table 1. Cont.

\begin{tabular}{|c|c|c|c|c|c|c|}
\hline ETHOS & Target Group & $\mathbf{n}$ & $\begin{array}{c}\text { After } \\
\text { Moving In }\end{array}$ & $\begin{array}{l}\text { After } 12 \\
\text { Months }\end{array}$ & $\begin{array}{l}\text { Variation } \\
\quad(\%)\end{array}$ & $\begin{array}{l}\text { Statistical Test } \\
\quad(p \text {-Value })\end{array}$ \\
\hline \multicolumn{7}{|c|}{ Debt assistance } \\
\hline & Total data sample & 147 & $11.6 \%$ & $18.4 \%$ & 6.8 & 0.026 \\
\hline \multirow{2}{*}{ Houseless } & $\begin{array}{l}\text { PPR (Previous place of } \\
\text { residence) hostel }\end{array}$ & 29 & $13.8 \%$ & $17.2 \%$ & 3.4 & 0.5 \\
\hline & PPR shelter & 33 & $12.1 \%$ & $27.3 \%$ & 15.2 & 0.063 \\
\hline Inadequate & PPR cottage or cabin & 8 & $25.0 \%$ & $0.0 \%$ & -25.0 & 0.25 \\
\hline Roofless & $\begin{array}{l}\text { PPR emergency shelter, } \\
\text { roofless }\end{array}$ & 6 & $0.0 \%$ & $0.0 \%$ & 0.0 & - \\
\hline \multirow[b]{2}{*}{ Insecure } & PPR rental/own housing & 44 & $4.5 \%$ & $11.4 \%$ & 6.8 & 0.125 \\
\hline & $\begin{array}{l}\text { PPR transitional } \\
\text { (temporary) housing }\end{array}$ & 20 & $25.0 \%$ & $30.0 \%$ & 5.0 & 0.5 \\
\hline \multirow[t]{4}{*}{-} & Other & 4 & $0.0 \%$ & $25.0 \%$ & 25.0 & 0.5 \\
\hline & $\begin{array}{c}\text { less than } 3 \text { contacts with a } \\
\text { SW per month }\end{array}$ & 50 & $6.0 \%$ & $6.0 \%$ & 0.0 & - \\
\hline & $\begin{array}{l}3 \text { to } 4 \text { contacts with a SW } \\
\text { per month }\end{array}$ & 44 & $15.9 \%$ & $38.6 \%$ & 22.7 & 0.006 \\
\hline & $\begin{array}{l}5 \text { and more contacts with a } \\
\text { SW per month }\end{array}$ & 44 & $15.9 \%$ & $15.9 \%$ & 0.0 & 0.637 \\
\hline \multicolumn{7}{|c|}{ Housing situation assistance } \\
\hline & Total data sample & 147 & $59.2 \%$ & $32.7 \%$ & -26.5 & $<0.001$ \\
\hline \multirow{2}{*}{ Houseless } & $\begin{array}{l}\text { PPR (Previous place of } \\
\text { residence) hostel }\end{array}$ & 29 & $72.4 \%$ & $24.1 \%$ & -48.3 & $<0.001$ \\
\hline & PPR shelter & 33 & $54.5 \%$ & $36.4 \%$ & -18.2 & 0.105 \\
\hline Inadequate & PPR cottage or cabin & 8 & $37.5 \%$ & $25.0 \%$ & -12.5 & 0.5 \\
\hline Roofless & $\begin{array}{l}\text { PPR emergency shelter, } \\
\text { roofless }\end{array}$ & 6 & $83.3 \%$ & $33.3 \%$ & -50.0 & 0.125 \\
\hline \multirow{6}{*}{ Insecure } & PPR rental/own housing & 44 & $52.3 \%$ & $25.0 \%$ & -27.3 & 0.002 \\
\hline & $\begin{array}{l}\text { PPR transitional } \\
\text { (temporary) housing }\end{array}$ & 20 & $55.0 \%$ & $45.0 \%$ & -10.0 & 0.344 \\
\hline & Other & 4 & $75.0 \%$ & $50.0 \%$ & -25.0 & 0.5 \\
\hline & $\begin{array}{l}\text { less than } 3 \text { contacts with a } \\
\text { SW per month }\end{array}$ & 50 & $54.0 \%$ & $30.0 \%$ & -24.0 & 0.006 \\
\hline & $\begin{array}{l}3 \text { to } 4 \text { contacts with a SW } \\
\text { per month }\end{array}$ & 44 & $65.9 \%$ & $45.5 \%$ & -20.5 & 0.025 \\
\hline & $\begin{array}{l}5 \text { and more contacts with a } \\
\text { SW per month }\end{array}$ & 44 & $59.1 \%$ & $27.3 \%$ & -31.8 & 0.001 \\
\hline
\end{tabular}

Key social workers evaluated the intensity of support provided in households using special record tables, always after the quarter of a year of their work in households. Data were evaluated using linear modelling by estimating trend development (development curve) through linear models [26]. To evaluate the data, it is necessary to note that the data could only be evaluated for households for which social workers had records for at least two quarters of a year. In the presented data, we further worked with the averages of these trends and statistically tested their difference from zero. In this way, we revealed trends in the intensity of support provided by social work.

The total intensity of social work between individual quarters decreased in: number of interventions of a social worker $(-0.11, \mathrm{n}=175$ households, $p$-value $=0.002)$, total frequency of contacts with a social 
worker $(-0.541, \mathrm{n}=178$ households, $p$-value $<0.001)$ also in the average time spent on interventions $(-0.341, \mathrm{n}=181, p$-value $<0.001)$.

The declining need for social work interventions can be considered a significant impact of social housing. If we link this result with the declining need for support from social services in the area of social benefits, in support with the authorities and in the area of housing, it is clear that the provision of social housing leads to an overall reduction in social work and (possible) increase in client self-sufficiency, which can result in strong economic impacts of social housing in the form of savings for the provision of social work.

\section{Discussion and Conclusions}

Data from evaluation of 16 social housing systems of 16 municipalities in the Czech Republic provide an interesting and (in the Czech Republic in terms of the research sample size) a unique probe into the impact of social housing on the living conditions of homeless population. Our research also fills the research gap in the form of evaluating the impacts of the use of social housing on the use of social services outside the social housing project. It points out that these impacts are significant. Within the hypothesis we set, we assumed that there would be an increase in the use of social services for people living in social housing. This assumption was based on two basic assumptions. The first was that the use of social services would increase as a result of social workers in social housing networking clients to these services (e.g., informing them about, accompanying clients to services) and thus promoting their use. The second assumption was based on the fact that the users of social housing will stabilize the living situation in the form of gaining stable housing and, as a result, these users will focus on stabilizing the living situation in other areas (e.g., financial-i.e., benefits).

If only the use of social services was reduced (excluding the use of support in resolving debt issues), this result could be interpreted as meaning that users of social housing use this support instead of social services from social workers in the field of social housing. In the context of an overall decrease in the need for support from social workers in social housing, the above results can be interpreted as providing social housing leading to an overall reduction in the need for social work and (possible) increase in client self-sufficiency, which may result in the strong economic impacts of social housing in the form of savings for the provision of social work. The results of the research can also be summarized as social housing supports the sustainability of social services precisely by reducing the use of certain services, which brings significant savings.

The results of the social housing evaluation achieved by our team did not broadly confirm the results achieved by [12] or [17] in the Czech environment mentioned in the introduction of this article (which is logical given that, the evaluation, see [17], also included services provided within social housing), but at the same time, showed a significant impact of social housing on social work provided. Within the limits of achieved research results, we need to re-emphasize that the variability of the collected data in individual priority target groups of social housing in the Czech Republic indicates that there is a need to obtain a larger dataset from social housing evaluations. The validity of the data collected could also be supported by the use of a control sample of those who are not provided with social housing, ideally in the form of pairing of households based on similarities (e.g., target group, number of household members, age, previous housing trajectories, etc.). Despite their limits, the data indicate that social housing and related social work have the potential to improve the living conditions of homeless people.

Today, the Social Housing Act that would impose an obligation on municipalities to provide social housing has not been drafted in the Czech Republic. Thus, there is still a significant number of homeless people on the street, as well as a number of people at risk of homelessness, and it is up to individual municipalities to decide whether or not to help them in their life situation, and alternatively whether they create a local social housing system and to what capacity extent. In the conclusion of this paper, we can emphasize the need for a law on social housing in the Czech Republic, because the fundamental evaluation results showed that it stabilizes people in housing. In other words, it can be 
said that the situation of homeless people in the Czech Republic is not sustainable without imposing an obligation on municipalities to provide social housing.

Author Contributions: K.G. and M.M. were responsible for meta-analysis of literature to the topic, data interpretation and article composition. P.R. was responsible for data analysis and interpretation. All authors have read and agreed to the published version of the manuscript.

Funding: The text was funded by: Social housing-methodological and information support in the area of social agendas (CZ.03.2.63/0.0/0.0/15_017/0003539) and by SGS05/IRAFM/2020: Imagined interactions in the interssesion process in social work with homeless children and their families.

Conflicts of Interest: The authors declare no conflict of interest.

\section{References}

1. Cooper, J.; Walsh, C.A.; Smith, P. A Part of the Community: Conceptualizing Shelter Design for Young, Pregnant, Homeless Women. J. Assoc. Res. Mothering 2009, 11, 122-133.

2. RILaSA. Sčítání Osob Bez Domova [Homeless People Census]. Available online: http://praha.vupsv.cz/ fulltext/vz_458.pdf (accessed on 22 February 2020).

3. MoLSA Social Housing Concept of Czech. Republic 2015-2025. Available online: https://www.mpsv.cz/files/ clanky/27267/Koncepce_socialniho_bydleni_CR_2015--2025.pdf (accessed on 22 February 2020).

4. MoLSA. Tisková zpráva-Vláda Schválila Návrh Zákona o Sociálním Bydlení a o Příspěvku na Bydlení 2017 [Press release-The government approved the bill on social housing and the housing allowance.]. Available online: https://www.mpsv.cz/documents/20142/578124/Vlada_schvalila_zakon_o_socialnim_bydleni.pdf/ 72930daa-f9a6-94fd-3c8b-5f6dc63fe214 (accessed on 22 February 2020).

5. MoLSA. Statistická Ročenka z Oblasti Práce a Sociálních Věcí 2018 [Statistical Yearbook of Labor and Social Affairs 2018]; MPSV: Praha, Czech Republic, 2019.

6. Pleace, N. Housing First Guide Europe. Available online: https://housingfirsteurope.eu/ (accessed on 22 February 2020).

7. Mikulec, M.; Pazlarová, H. Sociální práce v sociálním bydlení [Social Work in Social Housing]. In Metodika Sociální Práce v Sociálnim Bydlení. Sešit Úvod do Tématu Sociální Práce v Sociálním bydlení [Methodology of Social Work in Social Housing. Workbook Introduction to the Topic of Social Work in Social Housing]; Mikulec, M., Šnejdrlová, M., Eds.; MPSV: Praha, Czech Republic, 2019.

8. Mikulec, M.; Šnejdrlová, M. Metodika Sociální Práce v Sociálním Bydlení. Sešit Úvod do Tématu Sociální Práce v Sociálním Bydlení. Sešit Nejčastějši Oblasti Podpory Klientio v Sociálním Bydlení [Methodology of Social Work in Social Housing. Workbook Introduction to the Topic of Social Work in Social Housing. Workbook the Most Common Areas of Client Support in Social Housing]; MPSV: Praha, Czech Republic, 2019.

9. Glumbíková, K.; Gojová, A.; Grunundělová, B. Critical reflection of the reintegration process through the lens of gender oppression: The case of social work with mothers in shelters. Eur. J. Soc. Work. 2018, 22, 575-586. [CrossRef]

10. Busch-Geertsema, V. Housing First Europe Final Report; European Union Programme for Employment and Social Solidarity_PROGRESS: Bremen, Germany, 2013.

11. Supplemental Material for The Effectiveness of Housing Interventions and Housing and Service Interventions on Ending Family Homelessness: A Systematic Review. Am. J. Orthopsychiatry 2014, 84, 457-474. [CrossRef] [PubMed]

12. Aubry, T.; Nelson, G.; Tsemberis, S. Housing First for People with Severe Mental Illness Who are Homeless: A Review of the Research and Findings from the at Home-Chez soi Demonstration Project. Can. J. Psychiatry 2015, 60, 467-474. [CrossRef] [PubMed]

13. Gubits, D.; Shinn, M.; Bell, S.; Wood, M.; Dastrup, S.R.; Solari, C.; Brown, S.R.; Brown, S.; Dunton, L.; Lin, W.; et al. Family Options Study: Short-Term Impacts of Housing and Services Interventions for Homeless Families. SSRN Electron. J. 2017. [CrossRef]

14. Fower, P.D.B.; Schoeny, M.; Chung, S. Homelessness in the child welfare system: A randomized trial to assess the impact of permanent housing on foster care placements and costs. N/A. Child. Abus. Negl. 2018, 83, 52-61. [CrossRef] [PubMed] 
15. Johnson, G.; Chamberlain, C. Evaluation of the Melbourne Street to Home Program: 12 month outcomes; Department Government Department of Families, Housing, Community Services and Indigenous Affairs: Canberra, Australia, 2013.

16. Bretherton, J.; Pleace, N. Housing First in England: An. Evaluation of Nine Services; University of York, Centre for Policy Housing: York, UK, 2015.

17. Ripka, Š.; Černá, E.; Kubala, P. Dopady Zabydlení po 12 Měsících od Nastěhování. Pilotní Testování Rychlého Zabydlení Rodin s Dětmi (Rapid Re-Housing). Závěrečná Evaluační Zpráva/Analýza Cílového Stavu [Impacts of Living 12 Months after Moving in. Pilot Testing of Rapid Re-housing. Final Evaluation Report]; University of Ostrava: Ostrava, Czech Republic, 2018.

18. Act on Social Services No.108/2006; Sbirka zakonu: Nakladatelství Sagit, Czech Republic, 2006.

19. Glumbíková, K. Bariéry ve využiváni veřejných služeb limi bez domova [Barriers to the Use of Public Services by People without a Home]; Sít' aktérů pro domov, z. s.: Ostrava, Czech Republic, 2018.

20. Ensign, J.; Panke, A. Barriers and Bridges to Care: Voices of Homeless Female Adolescent Youth in Seattle, Washington, US. J. Adv. Nurs. 2002, 37, 166-172. [CrossRef] [PubMed]

21. Kissane, R.J. What's Need Got to Do with It? Barriers to Use of Nonprofit Social Services. J. Sociol. Soc. Welf. 2003, 30, 127-148.

22. Ravenhill, M.H. The Culture of Homelessness: An. Etnographic Study. PhD Thesis, London School of Economics, UMI Dissertation Publishing, London, UK, 2003.

23. Gojová, A.; Glumbíková, K.; Kučera, P.; Lesák, V.; Ripka, Š. Jednotná Metodika Monitorování a Hodnocení Místních Systému Sociálního Bydlení [Unified Methodology of Monitoring and Evaluation of Local Social Housing Systems]; MPSV: Praha, Czech Republic, 2018.

24. Feantsa. ETHOS. Available online: https://www.feantsa.org/en/toolkit/2005/04/01/ethos-typology-onhomelessness-and-housing-exclusion (accessed on 22 February 2020).

25. Bouzarovski, S.; Thompson, H.; Varo, A.; Guyet, R. Towards an Inclusive Energy Transition in the European Union: Confronting Energy Poverty Amidst a Global Crisis; EU Energy Poverty Observatory, Publications Office of the European Union: Luxembourg, Switzerland, 2020.

26. Faraway, J.J. Extending the Linear Model with R: Generalized Linear, Mixed Effects and Nonparametric Regression Models; CRC Press: Boca Raton, FL, USA, 2016.

Publisher's Note: MDPI stays neutral with regard to jurisdictional claims in published maps and institutional affiliations.

(C) 2020 by the authors. Licensee MDPI, Basel, Switzerland. This article is an open access article distributed under the terms and conditions of the Creative Commons Attribution (CC BY) license (http://creativecommons.org/licenses/by/4.0/). 